Article

\title{
"Zero-Waste": A Sustainable Approach on Pyrometallurgical Processing of Manganese Nodule Slags
}

\author{
Marcus Sommerfeld ${ }^{1, * \mathbb{C}}$, David Friedmann ${ }^{1}$, Thomas Kuhn ${ }^{2}$ and Bernd Friedrich ${ }^{1}$ \\ 1 Department of Process Metallurgy and Metal Recycling (IME), RWTH Aachen University, Intzestraße 3, \\ D-52056 Aachen, Germany; dfriedmann@ime-aachen.de (D.F.); bfriedrich@ime-aachen.de (B.F.) \\ 2 Federal Institute for Geosciences and Natural Resources (BGR), Stilleweg 2, D-30655 Hannover, Germany; \\ thomas.kuhn@bgr.de \\ * Correspondence: msommerfeld@ime-aachen.de; Tel.: +49-241-80-95-200
}

Received: 19 September 2018; Accepted: 17 November 2018; Published: 23 November 2018

\begin{abstract}
A continuously growing demand for valuable non-ferrous metals and therefore an increase in their prices at the metal exchanges makes it necessary and profitable to investigate alternative metal resources. Polymetallic deep-sea nodules contain cobalt, copper, manganese, molybdenum and nickel, and are highly abundant on the sea floor. Developing a metallurgical process to recover the metal content from manganese nodules can close the predicted supply gap of critical metals like cobalt. This paper investigated a potential extraction process for valuable metals from manganese nodules supplied by the German Federal Institute for Geosciences and Natural Resources. The samples originated from the German license area of the Clarion-Clipperton Zone in the Pacific Ocean. Due to a low concentration of valuable metals in nodules, a pyrometallurgical enrichment step was carried out to separate cobalt, copper, molybdenum and nickel in a metallic phase. The manganese was discarded in the slag and recovered in a second smelting step as ferromanganese. To aid the experiments, FactSage $^{\mathrm{TM}}$ was used for thermodynamic modeling of the smelting steps. To increase metal yields and to alter the composition of the metal alloys, different fluxes were investigated. The final slag after two reduction steps were heavy-metal free and a utilization as a mineral product was desired to ensure a zero-waste process.
\end{abstract}

Keywords: marine mineral resources; manganese nodules; pyrometallurgical treatment; zero-waste processing; direct slag reduction; thermodynamic modeling

\section{Introduction}

The exploration of polymetallic deep-sea nodules as a multi-metallic resource is an ongoing research object since the first extensive exploration phase in the 1960s and 1970s. Due to an increase in metal prices and a continuously high demand for various metals, another extensive phase of exploration started at the beginning of this century. Several governmental and semi-governmental institutions signed contracts with the International Seabed Authority to investigate polymetallic deep-sea nodules and since 2010 private enterprises have also done so. The most promising area for exploitation of this marine resource is the Clarion-Clipperton Fracture Zone (CZZ) in the Pacific Ocean [1]. Around $15 \mathrm{~kg}$ of manganese nodules per square meter on average cover the seafloor in an area the size of five million square kilometers [2].

Metals of interest in deep-sea nodules are especially copper, cobalt and nickel. Due to the high abundance of nodules on the deep-sea floor, the reserves for those metals are significant $[3,4]$. Furthermore, the recovery of manganese, molybdenum and vanadium is of interest or at least the 
enrichment of a marketable by-product can add value to an extraction process [3]. Table 1 shows a comparison of estimated reserves for the mentioned valuable metals in manganese nodules and in land-based ore bodies, which highlights why manganese nodules are an interesting potential resource [4].

Table 1. Comparison of the estimated resources for metals in manganese nodules in the Clarion-Clipperton Fracture Zone (CCZ) and the land-based reserve base (million metric tons) [4].

\begin{tabular}{cccccc}
\hline Resource & Co & Cu & Mn & Mo & Ni \\
\hline Nodules in CCZ & 42 & 224 & 5929 & 12 & 278 \\
Global land-based & 13 & 1300 & 5200 & 19 & 150 \\
\hline
\end{tabular}

The expected resources of cobalt, manganese and nickel in manganese nodules solely in the CCZ surpass the reserves of those metals on land [4]. Due to the abundance of high-grade manganese ore on land, utilizing the nodules as a source of copper and nickel only is of interest [5]. A process that additionally recovers cobalt is desirable due to the criticality of cobalt and its importance in the area of clean energy technology [6]. More than one half of global cobalt mine production currently comes from the Democratic Republic of the Congo and since the predicted consumption increases faster than the world cobalt refinery capacity, a limited supply is expected. Most cobalt is already mined as a by-product of nickel and copper production [7], therefore the recovery of cobalt while extracting nickel and copper from manganese nodules can be considered a viable option to close the forecasted supply gap. A rising demand is also predicted for manganese alloys, however, metallurgical grade ores on land are distributed more evenly than cobalt [8], which minimizes a supply risk. To optimize the profitability of a metallurgical process and to decrease the mass of produced by-products with low or no economic value, the production of marketable manganese alloys seems to be an apparent necessity to utilize manganese-rich streams.

Several metallurgical processes underwent experimental trials. In general, different extraction processes for utilizing manganese nodules could be categorized into hydrometallurgical processes and pyrometallurgical enrichment processes with subsequent hydrometallurgical downstream processing to separate valuable metals. Already in the 1970s, the International Nickel Corporation (Inco) proposed a process, the so-called "Inco-process" [5], to utilize polymetallic deep-sea nodules as a resource for nickel, copper and cobalt. The process is based on well-known metallurgical unit operations like drying, selective reduction, smelting, oxidizing, sulfiding and converting. Valuable metals like nickel, copper and cobalt are concentrated in an early stage of the process by reduction into a metallic phase and manganese is mainly discarded in the manganese-silicate slag. Excess iron and manganese in the metal is converted to reduce the weight of the valuable metal stream. A matte is produced by sulfiding the reduced metal. Compared to the weight of the nodules, the matte weighs only $5 \mathrm{wt} \%$ and is processed further by hydrometallurgical unit operations to separate nickel, copper and cobalt. Due to the abundance of high-grade manganese deposits on land, the recovery of manganese from the manganese-silicate slag was not investigated in detail by Inco [5]. A simplified flowchart of the pyrometallurgical enrichment process by Inco is displayed in Figure 1.

In comparison to the pyrometallurgical treatment of polymetallic nodules, there are also several hydrometallurgical processes under investigation; however there are a few major disadvantages with these processes, especially, the high consumption of chemicals like acids or bases and considerable amounts of leach residues and precipitation by-products that seem to be a high burden for the environment [9]. A sole hydrometallurgical process can only be economically feasible if reagents are cheap or can be recycled easily. The major disadvantage of a pyrometallurgical process is the energy consumption of drying and smelting of nodules [10], however, less extensive downstream processing to recover valuable metals and the possibility of manganese recovery from slag can possibly outweigh these disadvantages $[9,11]$. 


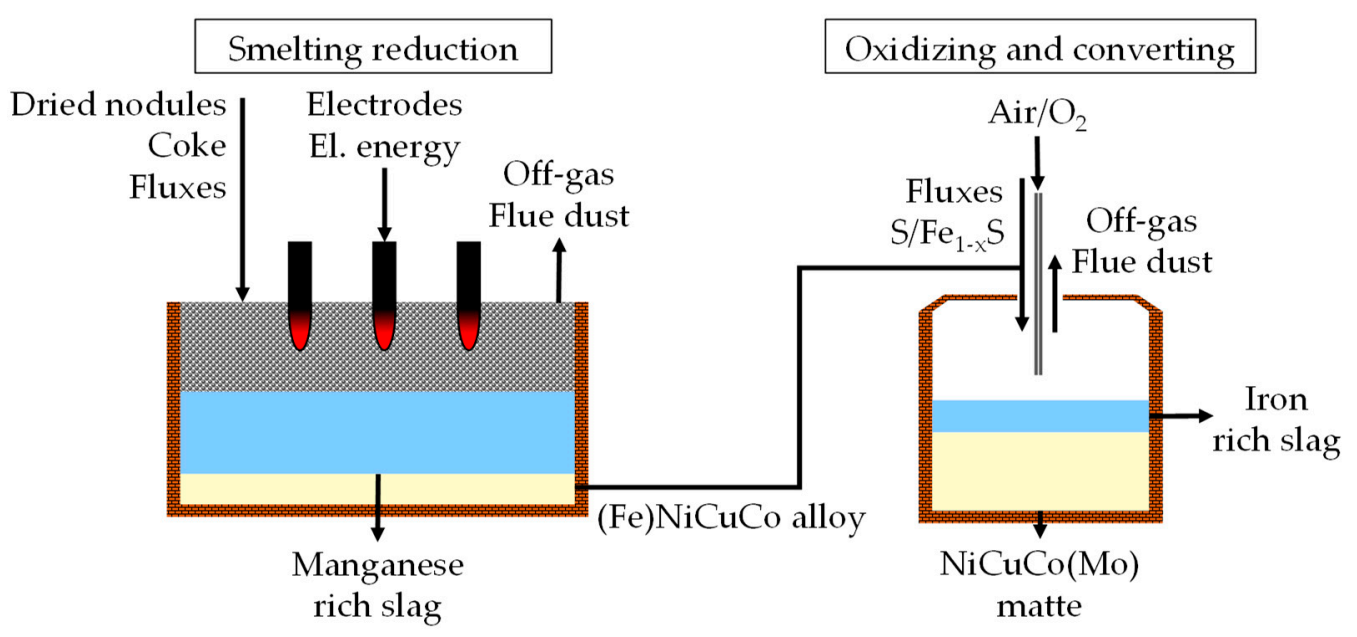

Figure 1. Simplified flowchart of the pyrometallurgical Inco-process [5].

The aim of this study was to investigate the smelting reduction operation from the Inco-process. Inco proposed a smelting reduction operation without the addition of fluxes [5]. However, to decrease the liquidus temperature and to improve the recovery of metals, the addition of fluxes can be beneficial [3]. Previous research explored the option of adding silica [3,12] or silica and lime [13]. To alter the smelting behavior and to increase the degree of reduction for valuable metals, this paper explored the usage of different additives and variations in the added amount of fluxes to the nodules. To support the design of the experimental trials FactSage ${ }^{\mathrm{TM}} 7.0$ was used. FactSage ${ }^{\mathrm{TM}}$ is a thermochemical modeling program [14]. In this article liquidus temperatures of smelting operations, activities of oxides, degree of reduction and the composition of phases like slag or alloys were predicted by FactSage ${ }^{\mathrm{TM}}$.

Furthermore, the possibility of manganese recovery utilizing the resulting manganese-rich slag as a resource to produce high carbon ferromanganese ( $\mathrm{HC} \mathrm{FeMn)} \mathrm{in} \mathrm{a} \mathrm{second} \mathrm{smelting} \mathrm{reduction} \mathrm{process}$ was proposed. The effects of adding lime and magnesia as a flux in the second smelting reduction step on the composition of the final alloy and slag were examined and modeled by FactSage ${ }^{\mathrm{TM}}$. Those fluxes are commonly used in the production of ferromanganese in a submerged arc furnace from land-based ore bodies. The main objective of the addition of basic fluxes was to increase the manganese yield and to decrease the silicon content in the produced alloy [15]. Figure 2 shows the flowchart of the process investigated by this paper. For both reduction operations, submerged arc furnaces were recommended. The advantages of such a furnace for processing manganese nodules were already highlighted in previous research $[3,5]$. For producing ferromanganese, the submerged arc furnace is already the dominant furnace in the industry [15].

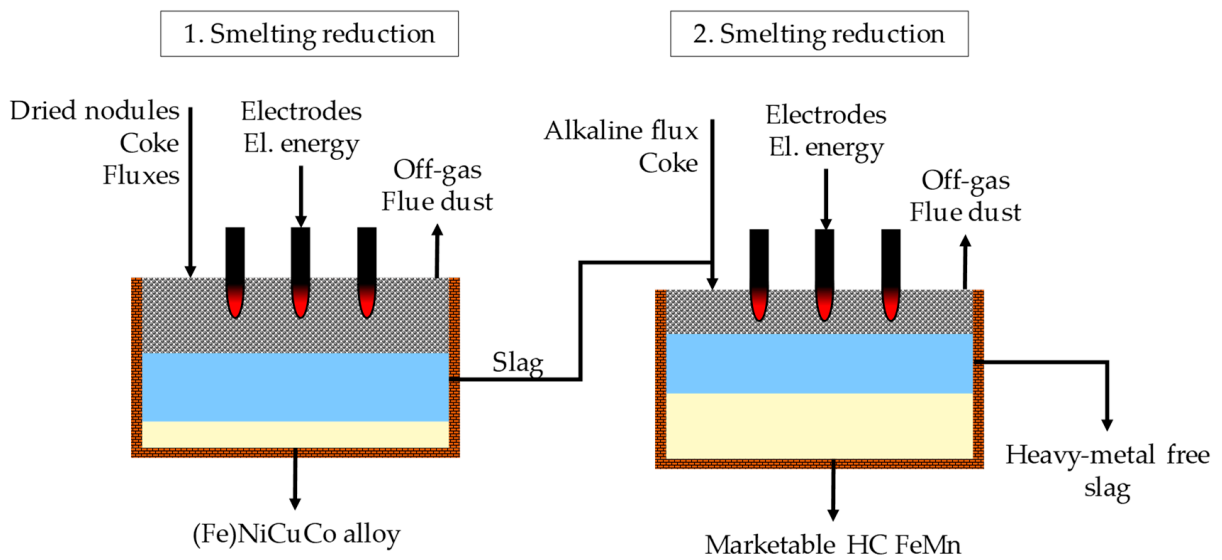

Figure 2. Simplified flowchart of the investigated process. 
By combining two smelting reduction processes, the following advantages were expected:

- Valuable metals are concentrated in an alloy in the first reduction step, to minimize hydrometallurgical downstream processing.

- By production of marketable ferromanganese, value can be added to the entire production process.

- After two reduction processes, it is envisaged to generate a heavy-metal free slag, which can be used as a construction material to avoid landfilling of slag and therefore reduce the burden on the environment.

\section{Thermochemistry}

\subsection{Thermochemistry of Manganese Nodule Smelting}

The purpose of the first reduction step in Figure 2 is to discard manganese in the slag and to enrich the valuable metals in an alloy, to simplify further downstream processing [5]. For a successful slagging operation, the activity of the oxide that should stay in the slag has to be low. A component with a high activity has the tendency to leave the system [16], for example by reduction and dissolving in a metallic phase in this case. For manganese(II) oxide, this can be expressed by Equation (1):

$$
\mathrm{MnO}_{(1)}+\mathrm{C}_{(\mathrm{s})} \rightleftharpoons \mathrm{Mn}_{(1)}+\mathrm{CO}_{(\mathrm{g})}
$$

where (s) denotes components in a solid state; (l) denotes components in a liquid state; and (g) denotes components in gaseous state.

Therefore, to design a suitable slag composition a low activity of manganese(II) oxide in the slag is desirable to discard most of the manganese in the slag. The influence of different fluxes on the activity of manganese(II) oxide was simulated with FactSage ${ }^{\mathrm{TM}}$ and displayed in Figure 3 at the liquidus temperature of the slag and a pressure of $1 \mathrm{~atm}$.

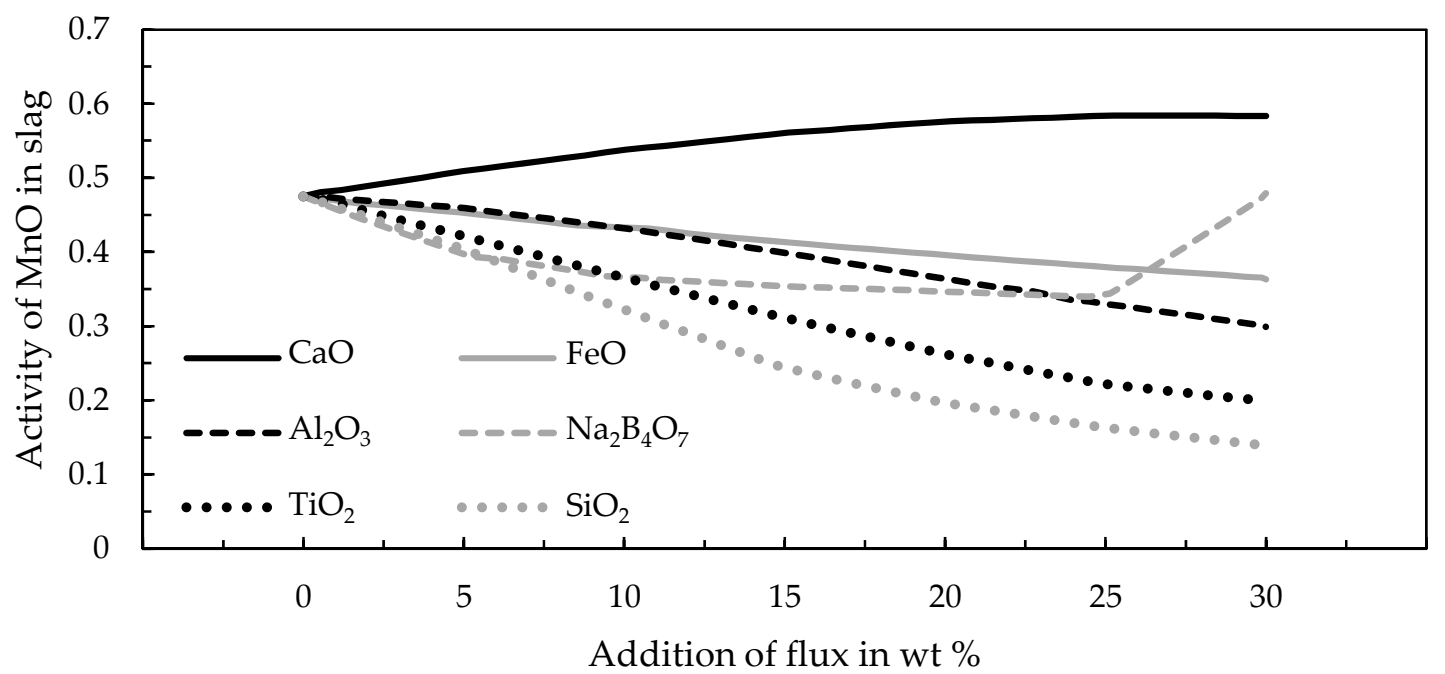

Figure 3. Influence of fluxing on MnO-activity based on FactSage ${ }^{\mathrm{TM}}$.

Fluxing by $\mathrm{Al}_{2} \mathrm{O}_{3}, \mathrm{TiO}_{2}, \mathrm{FeO}, \mathrm{Na}_{2} \mathrm{~B}_{4} \mathrm{O}_{7}$ and $\mathrm{SiO}_{2}$ resulted in an activity decrease of manganese(II) oxide in the slag, however, after the addition of $25 \mathrm{wt} \% \mathrm{Na}_{2} \mathrm{~B}_{4} \mathrm{O}_{7}$ the activity increased again. $\mathrm{CaO}$ is not an appropriate fluxing agent for the smelting of manganese nodules, due to an increase in manganese(II) oxide activity in the slag. The most promising results were reached by the addition of $\mathrm{SiO}_{2}$ as a flux. Therefore, in the experimental trials, a special emphasis was given to the effect of $\mathrm{SiO}_{2}$ on the smelting operations. Different additions of $\mathrm{SiO}_{2}$, mixtures of fluxes containing $\mathrm{SiO}_{2}$ and furthermore three other pure oxides were investigated. The fluxes and the amount are listed in Table 2, together with the liquidus temperature of the slag predicted by FactSage ${ }^{\mathrm{TM}}$. 
Table 2. Effect of flux on liquidus temperature and basicity, modeled with FactSage ${ }^{\mathrm{TM}}$ for smelting nodules.

\begin{tabular}{|c|c|c|c|c|c|c|c|c|}
\hline Fluxing & No Addition & $15 \% \mathrm{SiO}_{2}$ & $25 \% \mathrm{SiO}_{2}$ & $\begin{array}{c}30 \% \\
\mathrm{SiO}_{2}-\mathrm{CaO} \\
\end{array}$ & $\begin{array}{c}20 \% \mathrm{SiO}_{2}-\mathrm{TiO}_{2} \\
10 \% \mathrm{Al}_{2} \mathrm{O}_{3}\end{array}$ & $25 \% \mathrm{TiO}_{2}$ & $\begin{array}{c}20 \% \\
\mathrm{Na}_{2} \mathrm{~B}_{4} \mathrm{O}_{7} \\
\end{array}$ & $20 \% \mathrm{Fe}_{2} \mathrm{O}_{3}$ \\
\hline $\mathrm{T}_{\text {Liq }}$ in ${ }^{\circ} \mathrm{C}$ & 1514 & 1263 & 1285 & 1365 & 1190 & 1204 & 1302 & 1403 \\
\hline
\end{tabular}

\subsection{Thermochemistry of Ferromanganese Production}

With FactSage ${ }^{\mathrm{TM}}$ the influence of lime and a mixture of $50 \mathrm{wt} \%$ lime and $50 \mathrm{wt} \%$ magnesia was investigated. The manganese yield and the silicon content in the alloy were of interest and are shown in Figure 4. The simulation was carried out under the assumption that graphite, slag and the alloy were in a thermal equilibrium at $1500^{\circ} \mathrm{C}$.

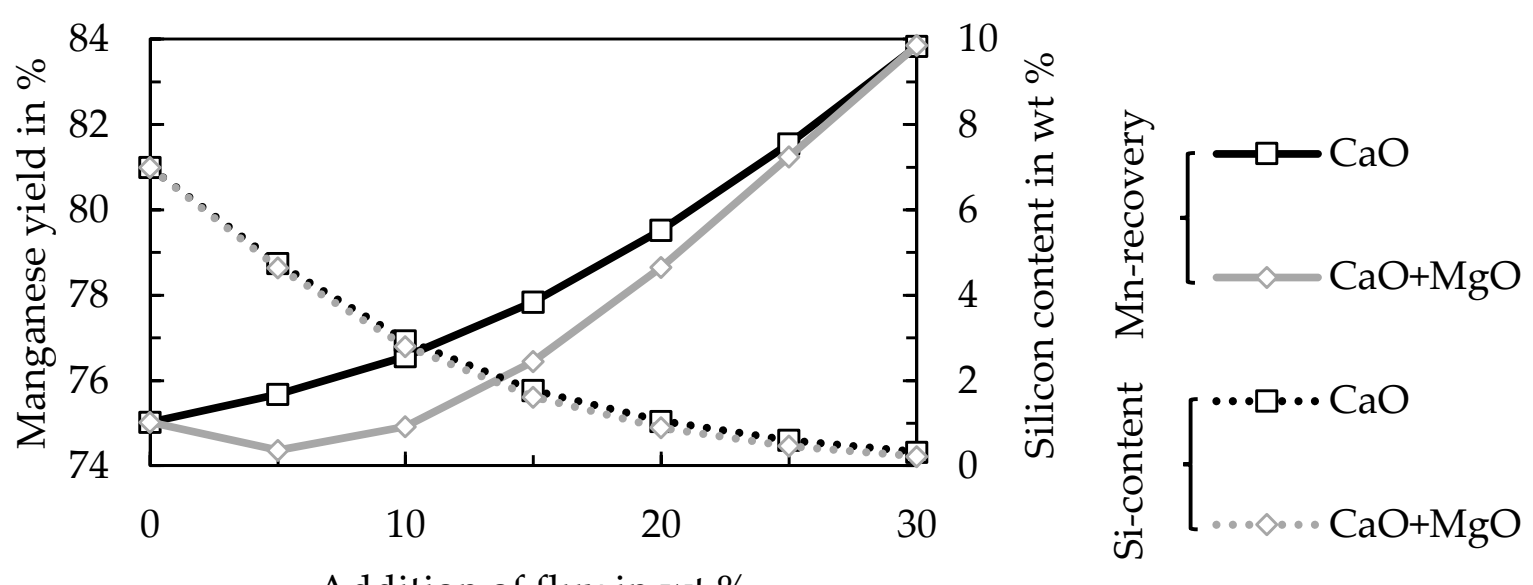

Addition of flux in wt \%

Figure 4. Influence of fluxing on the manganese yield and silicon content in the alloy.

According to the simulation, lime and the mixture of lime and magnesia had a positive effect on the manganese yield and the silicon content in the ferromanganese. The difference between the addition of solely lime and the mixture on the silicon content was rather small, however, there was a difference in the yield of manganese. The effect of lime on the yield was better than the effect of the lime and magnesia mixture, though this difference decreased if the addition of fluxes was increased up to $30 \mathrm{wt} \%$. The highest yield and lowest silicon content were achieved when $30 \mathrm{wt} \%$ of fluxes are added. Based on this simulation, five different slag compositions were considered for the experiments. Additionally, magnesia was considered as well. Table 3 shows the investigated fluxes and the liquidus temperature of the slag before reduction, based on FactSage ${ }^{\mathrm{TM}}$ and the basicity (B) of the slag according to Equation (2). The liquidus temperature of the slag without fluxing was $1279^{\circ} \mathrm{C}$.

$$
\mathrm{B}=\frac{\mathrm{wt} \% \mathrm{MgO}+\mathrm{wt} \% \mathrm{CaO}}{\mathrm{wt} \% \mathrm{SiO}_{2}}
$$

Table 3. Effect of flux on liquidus temperature and basicity, modeled with FactSage ${ }^{\mathrm{TM}}$ for ferromanganese production.

\begin{tabular}{cccccc}
\hline Fluxing & $\mathbf{5 \%} \mathbf{C a O}$ & $\mathbf{1 5} \% \mathbf{~ M g O}$ & $\mathbf{1 5 \%} \mathbf{C a O}-\mathbf{M g O}{ }^{*}$ & $\mathbf{1 5} \% \mathbf{C a O}$ & $\mathbf{3 0} \mathbf{C a O}$ \\
\hline $\mathrm{T}_{\mathrm{Liq}}$ in ${ }^{\circ} \mathrm{C}$ & 1308 & 1409 & 1335 & 1351 & 1401 \\
$\mathrm{~B}$ & 0.48 & 0.91 & 0.91 & 0.91 & 1.55 \\
\hline
\end{tabular}

${ }^{*}$ Mixture of $\mathrm{CaO}$ and $\mathrm{MgO}$ was $50 \mathrm{wt} \% \mathrm{CaO}$ and $50 \mathrm{wt} \% \mathrm{MgO}$; additions were in wt $\%$.

Even if fluxing by lime and magnesia increases the liquidus temperature, after reduction of manganese(II) oxide, fluxes are needed to keep the liquidus temperature under the process temperature 
of $1500{ }^{\circ} \mathrm{C}$. This prerequisite was met by all options presented in Table 3. In a simplified ternary phase diagram, containing the main oxides $\mathrm{MnO}, \mathrm{SiO}_{2}$ and $\mathrm{CaO}$, the path of the slag system during the process can be visualized. Such a diagram is shown in Figure 5, simulated by FactSage ${ }^{\mathrm{TM}}$ with a constant oxygen pressure of $0.01 \mathrm{~atm}$ as a boundary condition.

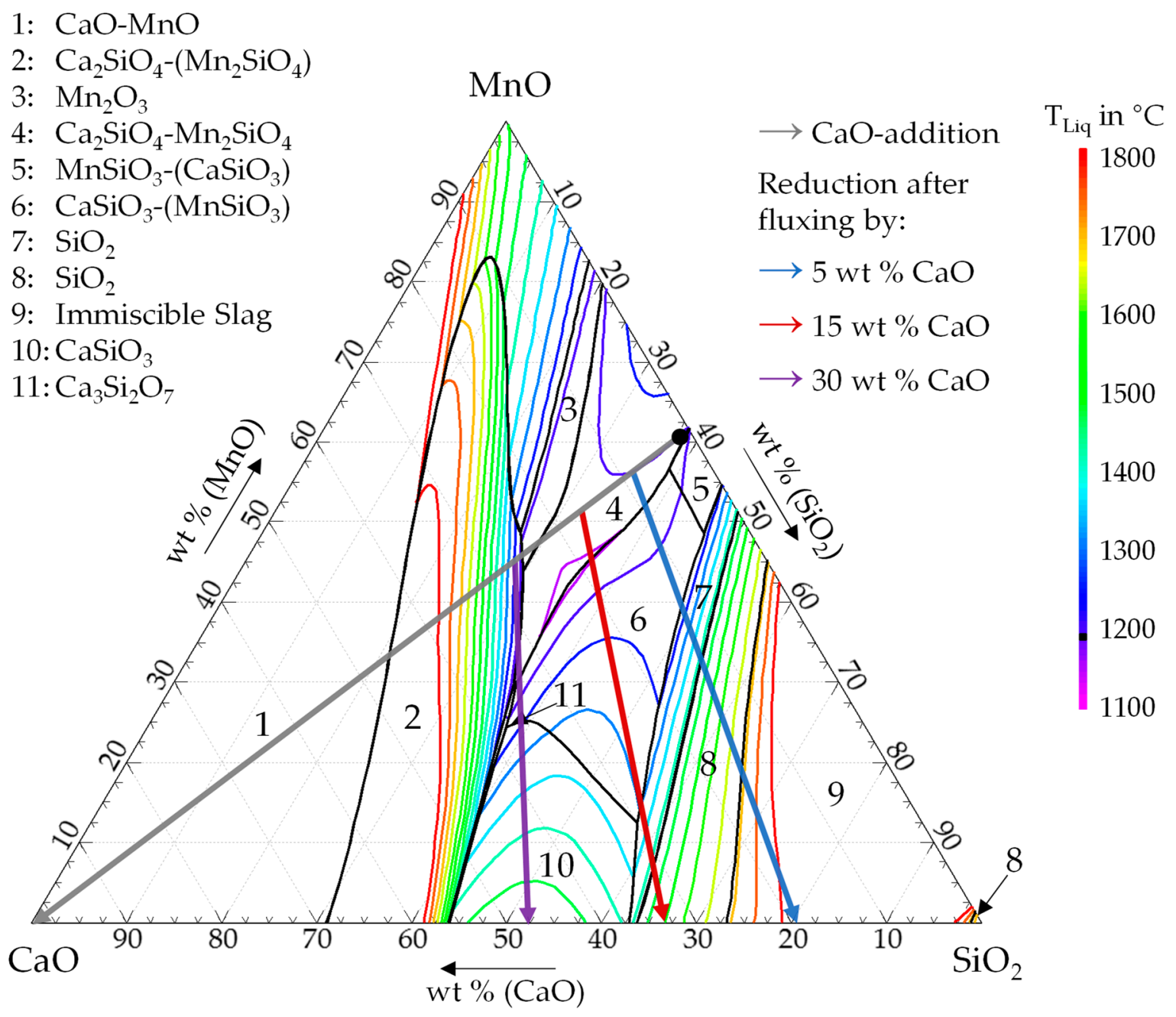

Figure 5. Isothermal liquidus curves of the $\mathrm{MnO}-\mathrm{SiO}_{2}-\mathrm{CaO}$ slag system and path of fluxing and reduction.

Such a diagram could only roughly support the development of the process, because the main oxides were solely investigated. However, it was obvious that an addition of alkaline earth metals, in this case lime, was necessary to keep the liquidus temperature low, while manganese(II) oxide was extracted to a large extent. The liquidus temperature of the nodule slag before reduction and fluxing was around $1280{ }^{\circ} \mathrm{C}$, displayed by the black dot in the diagram (Figure 5). Fluxing with lime increased the liquidus temperature by $4{ }^{\circ} \mathrm{C}$ per percent of added lime and is displayed by the grey line. The path of manganese reduction is displayed by the blue, red and purple lines for three different additions of lime. While manganese(II) oxide reduced, the liquidus temperature of the slag increased in each of the three investigated cases, however, the biggest increase occurred when only $5 \mathrm{wt} \%$ of lime was added. Fluxing with more than $15 \mathrm{wt} \%$ lime was theoretically necessary to sustain a liquid slag with a maximum of $10 \mathrm{wt} \%$ manganese(II) oxide. The liquidus temperature of such a slag was around $1425^{\circ} \mathrm{C}$. The components of the slag with the highest melting points were predicted by FactSage $\mathrm{T}^{\mathrm{TM}}$ and are indicated by the black phase boundaries. The chemical formulas of those components are given in Figure 5, while a silicate denoted in parenthesis was only a dilute component in the main 
silicate. A detailed description and the names of the phases in the FactSage ${ }^{\mathrm{TM}}$ database are listed in Table S1 of the Supplementary Information. Silicon oxides was the component with the highest melting point for trials with low additions of lime and calcium silicates having the highest melting point in the trials with more than $15 \mathrm{wt} \%$ additional lime.

\section{Materials and Experimental Details}

\subsection{Smelting of Manganese Nodules}

The deep-sea nodules studied in this research were a common sample from the German license area in the CCZ. The average chemical content of the valuable metals is presented in Table 4 [3].

Table 4. Average chemical content of valuable metals in dried deep-sea nodules from the German license area in the Clarion-Clipperton Fracture Zone (CCZ), analyzed by ICP-OES and ICP-MS (wt \%) [3].

\begin{tabular}{cccccc}
\hline Co & $\mathbf{C u}$ & Mn & Mo & Ni & V \\
\hline 0.16 & 1.17 & 31.2 & 0.06 & 1.36 & 0.06 \\
\hline
\end{tabular}

The manganese nodules were dried before the analysis, because they contained significant amounts of water. In addition to physically bound moisture, water of hydration was present in the nodules. The loss on ignition of dried nodules was still around $15 \mathrm{wt} \%$. The initial ratio of $\mathrm{MnO}$ to $\mathrm{SiO}_{2}$ in the measured samples was 3.2 [3].

The smelting experiments were carried out in a direct current (DC) electric arc furnace. The build-up of the furnace used for the smelting operation is shown in Figure 6. The supplied electrical power of the furnace is infinitely variable. The top electrode position is hydraulically adjusted by hand. After an experiment, the melt is poured into a coated casting mold. The tapping operation is also shown in Figure 6.

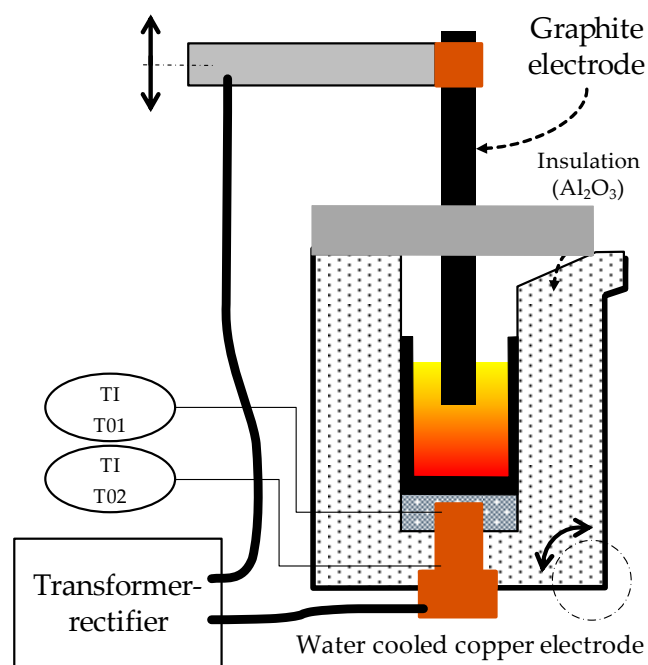

(a)

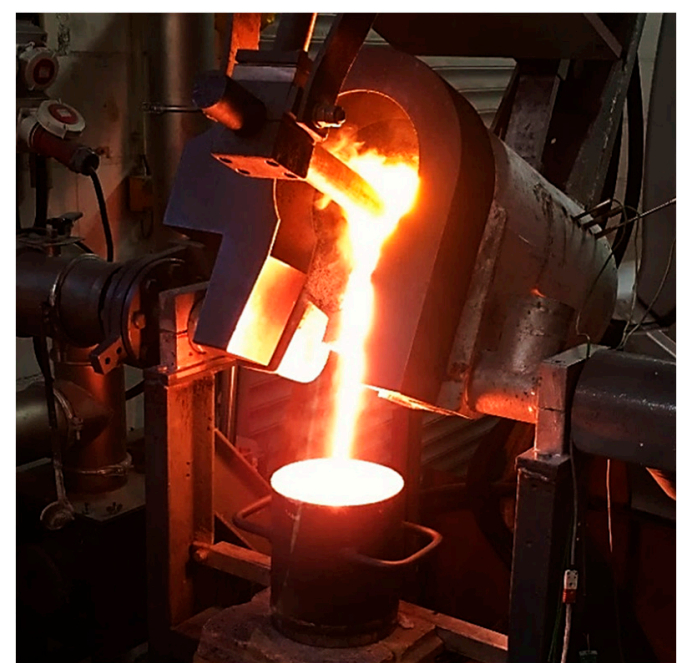

(b)

Figure 6. Small-scale electric arc furnace: (a) Schematic concept of the furnace; (b) tapping of the furnace after an experiment.

The smelting operation was carried out in a high purity graphite crucible. The working volume of the furnace was $2 \mathrm{~L}$. Approximately $3.5 \mathrm{~kg}$ of nodules were charged into the preheated furnace per trial. The fluxes shown in Table 2 were smelted together with the nodules. For every slag composition, four experiments were conducted. The graphite from the top electrode and crucible were used as a reducing agent. The reduction time, i.e., the time after all material is fed into the crucible was 20 min. 
The reduction temperature was about $150{ }^{\circ} \mathrm{C}$ above the modeled liquidus temperature of the slag (Table 2).

To verify the most promising results and to generate enough homogeneous material for the investigation of ferromanganese production, a second furnace was used to increase the mass of smelted nodules per experiment. The scale-up furnace is similar to the furnace in Figure 6 , but $8 \mathrm{~kg}$ of nodules could be smelted per trial. The working volume of the furnace was $6 \mathrm{~L}$. Six trials were carried out in this furnace and $48 \mathrm{~kg}$ of nodules were smelted in total. The temperature of the slag during the reduction time was $1400{ }^{\circ} \mathrm{C}$ and the reduction time was increased to $60 \mathrm{~min}$, due to the increased mass of nodules. To provide sufficient reducing agent, $200 \mathrm{~g}$ of carbon in the form of coke with a particle size between 1-5 mm was added per trial further to the carbon supply from the crucible and top electrode. After the reduction time, all coke reacted with the slag and gas.

Generated slag in this paper was analyzed by fused cast bead X-ray fluorescence spectroscopy (XRF) and the metal by a wavelength dispersive X-ray fluorescence spectroscopy (WDXRF) spectrometer. The carbon content in the metal was determined by an infrared absorption method after combustion in an induction furnace. The mass of the metallic phase and the slag was measured with a scale.

\subsection{Smelting of Manganese-Rich Slag}

The homogenized, crushed and screened manganese-bearing slag from the scale-up experiments was used for the production of ferromanganese following the process shown in Figure 2. For the smelting of manganese-rich slag, the small-scale electric arc furnace was used. $3 \mathrm{~kg}$ of slag was smelted together with fluxes in each experiment. The five combinations of fluxes shown in Table 3 were investigated. Every experiment was carried out twice. The smelting temperature was $1500{ }^{\circ} \mathrm{C}$. The reducing agent for the production of ferromanganese was the graphite from the crucible and top electrode as well. Furthermore, $6.2 \mathrm{wt} \%$ carbon was additionally added in the form of coke with a particle size between 1-5 mm. The reduction time was $60 \mathrm{~min}$, after this time all coke had reacted with the slag and gas.

\section{Results and Discussion}

\subsection{Smelting of Manganese Nodules}

To determine the efficiency of the smelting operation, the yield was calculated by using Equation (3):

$$
\eta_{\mathrm{x}}=100 \% \cdot \frac{\mathrm{m}_{\mathrm{x}_{\text {Metal }}}}{\mathrm{m}_{\mathrm{x}_{\text {Metal }}}+\mathrm{m}_{\mathrm{x}_{\text {Slag }}}}
$$

where $\eta_{\mathrm{x}}$ was the yield of element $\mathrm{x} ; \mathrm{m}_{\mathrm{x}_{\text {Metal }}}$ was the mass of the element $\mathrm{x}$ in the metal; and $\mathrm{m}_{\mathrm{x}_{\text {Slag }}}$ was the mass of the element $x$ in the slag. The mass of an element in a single phase was calculated with information about the total mass of the phase and the concentration of the element in that phase. The yield for the valuable metals and iron are shown in Figure 7 for the experiments in the furnace with a volume of $2 \mathrm{~L}$. To determine the efficiency of the slagging operation for manganese, the reciprocal value of the fraction from Equation (3) was displayed.

Due to the high manganese content in the slag and high yields for valuable metals, fluxing with $\mathrm{Na}_{2} \mathrm{~B}_{4} \mathrm{O}_{7}$ or $\mathrm{SiO}_{2}$ seemed to be beneficial. However, $\mathrm{Na}_{2} \mathrm{~B}_{4} \mathrm{O}_{7}$ is rather costly compared to $\mathrm{SiO}_{2}$, therefore only $\mathrm{SiO}_{2}$ was considered a viable option for a process on an industrial scale. In the trials, the addition of $15 \mathrm{wt} \% \mathrm{SiO}_{2}$ showed an advantage over the addition of $25 \mathrm{wt} \% \mathrm{SiO}_{2}$ and the mixtures containing $\mathrm{SiO}_{2}$ and other fluxes.

Based on the results in Figure 7, six scale-up trials were conducted. Compared to the small-scale trials, the $\mathrm{SiO}_{2}$-addition decreased to $9.4 \mathrm{wt} \%$. The average chemical composition of the main oxides in the slag is shown in Table 5. 


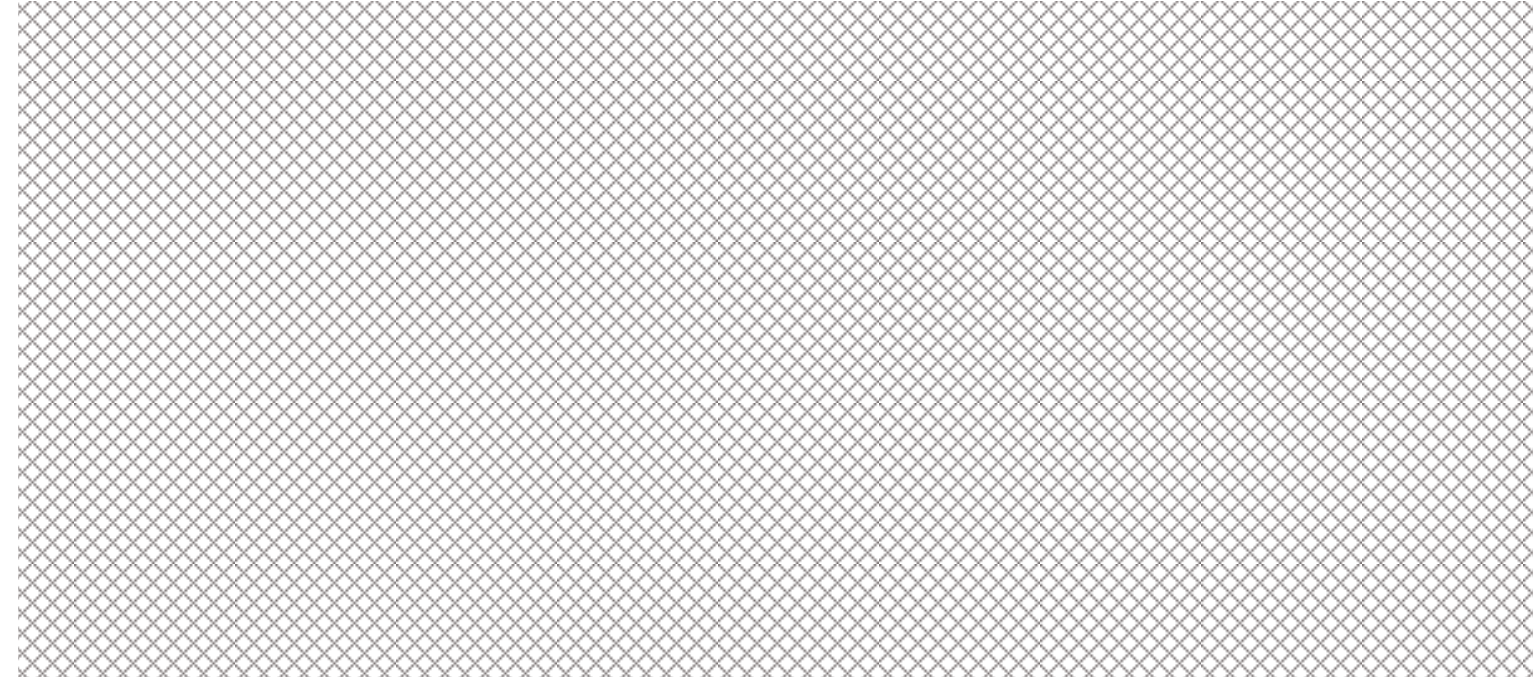

Figure 7. Yield of nodule smelting and the efficiency of the slagging operation.

Table 5. Average chemical composition of homogenized manganese-rich slag analyzed by fused cast bead XRF (wt \%).

\begin{tabular}{cccccccccc}
\hline $\mathrm{Al}_{2} \mathrm{O}_{3}$ & $\mathrm{CaO}$ & $\mathrm{CuO}$ & $\mathrm{FeO}$ & $\mathrm{MgO}$ & $\mathrm{MnO}$ & $\mathrm{Na}_{2} \mathrm{O}$ & $\mathrm{NiO}$ & $\mathbf{P}_{2} \mathrm{O}_{5}$ & $\mathrm{SiO}_{2}$ \\
\hline 5.64 & 2.92 & 0.15 & 1.57 & 3.34 & 56.2 & 4.46 & 0.07 & 0.20 & 23.4 \\
\hline
\end{tabular}

The average phase distribution for the investigated metallic elements is shown in Figure 8. Losses are neglected in this figure. The displayed margin of error is the standard deviation of all six trials.

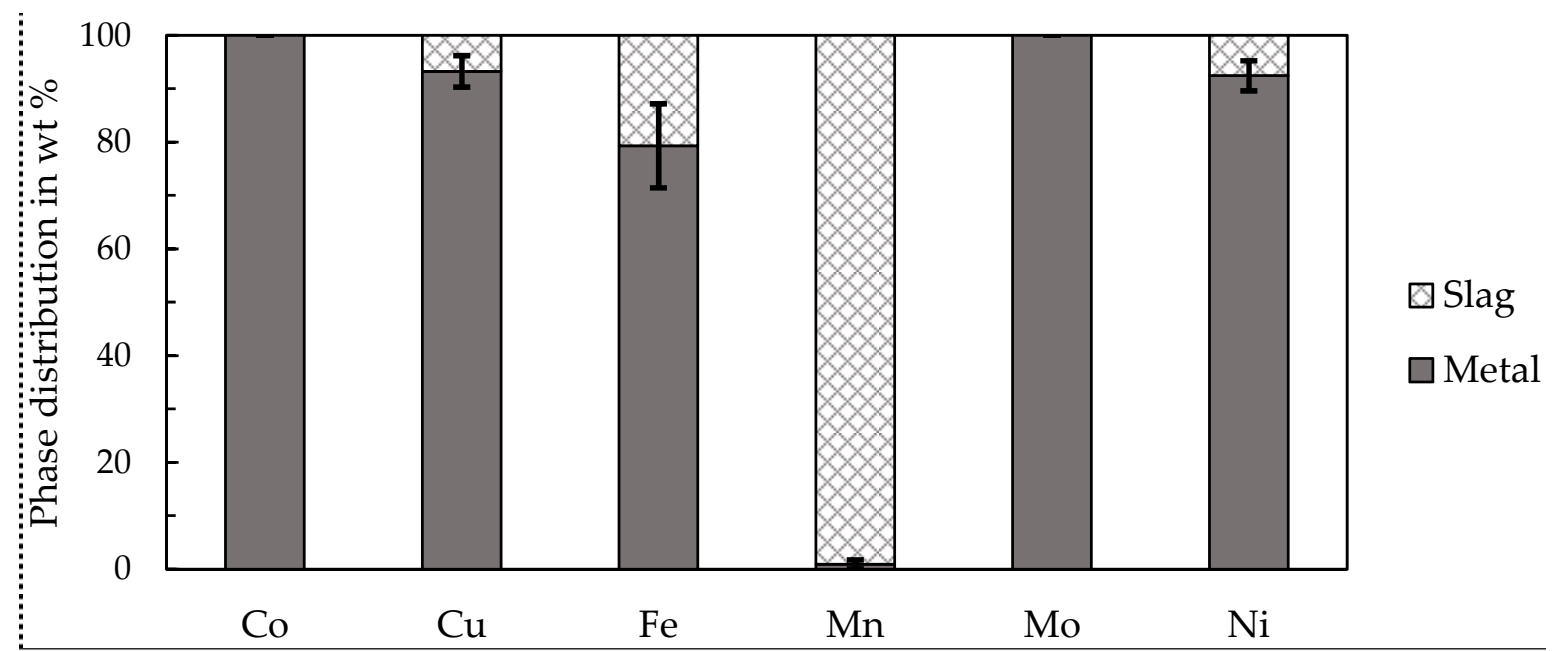

Figure 8. Average phase distribution for metallic elements between slag and metal for smelting experiments with $9.4 \mathrm{wt} \% \mathrm{SiO}_{2}$-addition.

The scale-up trials showed a similar high yield for cobalt, iron, molybdenum and nickel. The reduction of manganese was avoided successfully. The yield for copper with more than $90 \%$ was even higher than in the pre-trials. The high yield for iron of nearly $80 \%$ yielded an iron content in the alloy of over $50 \mathrm{wt} \%$, therefore, the iron content had to be reduced by the subsequent oxidizing and converting operation of the Inco-process to reduce the weight of the metal-bearing stream for downstream processing. 


\subsection{Smelting of Manganese-Rich Slag}

\subsubsection{Analysis of Ferromanganese}

Pre-trials showed that the content of manganese and silicon in the produced ferromanganese were the critical parameters, which had to be in line with the ASTM standard for grade A ferromanganese. The manganese content for that grade had to be above $78 \mathrm{wt} \%$ and the silicon content could not surpass $1.2 \mathrm{wt} \%$. The average values for those elements, based on two experiments per slag system are displayed in Figure 9 and compared to the values predicted by the FactSage ${ }^{\mathrm{TM}}$ model. The margins of error display the result of the first and second trial carried out for each slag system.

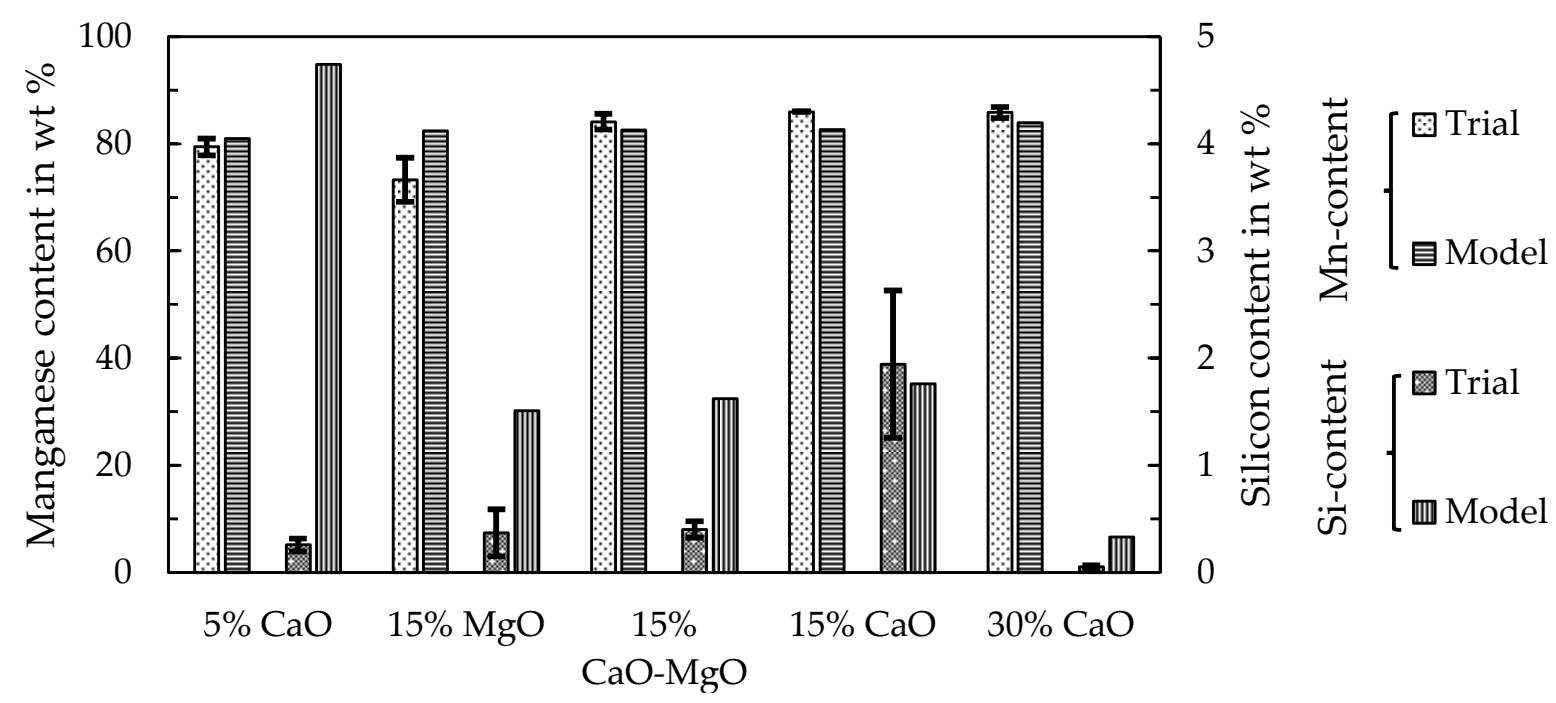

Figure 9. Comparison of the manganese and silicon contents in ferromanganese from experimental trials analyzed by WDXRF and the FactSage ${ }^{\mathrm{TM}}$ model under variation of fluxes.

Besides the experiments with an addition of $15 \mathrm{wt} \%$ magnesia, all alloys surpassed the minimum manganese content of $78 \mathrm{wt} \%$. Those results fairly matched the predicted values of the FactSage ${ }^{\mathrm{TM}}$ model, except for the experiments with $15 \mathrm{wt} \%$ magnesia, which were again out of line. The maximum silicon content in all alloys was under $1.2 \mathrm{wt} \%$, except for the trials with $15 \mathrm{wt} \%$ lime. However, the measured temperature of the slag before tapping for the trials with $15 \mathrm{wt} \%$ lime was $75^{\circ} \mathrm{C}$ higher than the planned $1500{ }^{\circ} \mathrm{C}$, even though a process temperature of $1500{ }^{\circ} \mathrm{C}$ would have been enough, to sustain a liquid slag during the reduction shown according to Figure 5 . Therefore, the higher silicon content compared to the trials with a lower addition of lime could be explained by the increased process temperature.

The margin of errors depends mostly on the process conditions since a steady operation in the small-scale electric arc furnace cannot be guaranteed during the whole experiment. Another major influence is the composition of the used raw material, which probably underlies inhomogeneity, even if homogenization of the supplied crushed slag is carried out by mixing before the experiments. With chemical analyses, inaccuracies due to sampling of the metal can be possible.

A comparison between the trials and the models in the case of silicon were not useful. All four trials with a tapping temperature of $1500^{\circ} \mathrm{C}$ had a significantly lower silicon content than the prediction by FactSage $\mathrm{e}^{\mathrm{TM}}$. This could be explained by the fact that FactSage ${ }^{\mathrm{TM}}$ only predicts the thermodynamical equilibrium, and after 60 min of reduction time it is not guaranteed that the equilibrium is already reached. In comparison to the ASTM standard for Grade A ferromanganese, the phosphorous, carbon and iron content of the alloys were no issue, because the tolerated maximum content of these elements was undercut easily. However, of concern is the high copper content around $0.4 \mathrm{wt} \%$ in the produced alloys. This content surpassed the amount of copper that was present in the manganese-rich slag as copper(II) oxide according to Table 5. The reason for this Cu-enrichment in ferromanganese may be 
due to copper-rich metal droplets, which have still been in the charged nodule slag. Even if the slag is crushed and screened before the experiments, it can be possible, that small droplets remained in the slag and contaminated the ferromanganese. By improving the metal and slag phase separation a lower copper content could be possible.

\subsubsection{Analysis of the Final Slag}

The final slag was analyzed and FactSage ${ }^{\mathrm{TM}}$ was used to model the liquidus temperature after the experiments. The basicity was again calculated by Equation (2). Table 6 shows the basicity and liquidus temperature for the investigated slags.

Table 6. Basicity and liquidus temperature of the final slag modeled with FactSage ${ }^{\mathrm{TM}}$.

\begin{tabular}{cccccc}
\hline Fluxing & $\mathbf{5 \%} \mathbf{C a O}$ & $\mathbf{1 5 \%} \mathbf{~ M g O}$ & $\mathbf{1 5 \%} \mathbf{C a O}-\mathbf{M g O}$ & $\mathbf{1 5 \%} \mathbf{C a O}$ & $\mathbf{3 0} \% \mathbf{C a O}$ \\
\hline $\mathrm{T}_{\mathrm{Liq}}$ in ${ }^{\circ} \mathrm{C}$ & 1312 & 1470 & 1357 & 1203 & 1284 \\
$\mathrm{~B}$ & 0.44 & 0.83 & 0.83 & 0.83 & 1.19 \\
\hline
\end{tabular}

Magnesia seemed to not be useful in the process since the liquidus temperature was only $30{ }^{\circ} \mathrm{C}$ lower than the proposed process temperature and as discussed before, the manganese content in the produced alloy was insufficient. Therefore, lime only seems to be an option for fluxing, an addition of $5-15 \mathrm{wt} \%$ is recommended. The liquidus temperature was low enough to ensure a liquid slag during the process and the produced alloys were in line with the ASTM standard. Fluxing with $30 \mathrm{wt} \%$ lime was not recommended because of two reasons, (i) the usage of so much flux is uneconomical and (ii) the slag of the experiments with $30 \mathrm{wt} \%$ lime tends to disintegrate, which prohibits the use of the slag as a mineral product in the construction industry.

For the development of a zero-waste process the final slag has to be a usable product. The content of heavy metals in the final slag should be as low as possible (Table 7).

Table 7. Amount of heavy metal traces in the final slag analyzed by fused cast bead XRF (wt \%).

\begin{tabular}{cccccc}
\hline Fluxing & $\mathbf{5 \%} \mathbf{C a O}$ & $\mathbf{1 5} \% \mathbf{~ M g O}$ & $\mathbf{1 5} \% \mathbf{C a O}-\mathbf{M g O}$ & $\mathbf{1 5} \% \mathbf{C a O}$ & $\mathbf{3 0} \% \mathbf{C a O}$ \\
\hline $\mathrm{Cr}_{2} \mathrm{O}_{3}$ & $<0.01$ & $<0.01$ & $<0.01$ & $<0.01$ & $<0.01$ \\
$\mathrm{CuO}$ & 0.11 & 0.04 & 0.05 & 0.03 & 0.03 \\
$\mathrm{NiO}$ & 0.09 & 0.01 & 0.02 & 0.01 & $<0.01$ \\
$\mathrm{~V}_{2} \mathrm{O}_{5}$ & 0.05 & $<0.01$ & 0.01 & $<0.01$ & $<0.01$ \\
\hline
\end{tabular}

The results showed that the concentration of most of the heavy metals in the slag was already low. The highest concentration was $0.11 \mathrm{wt} \%$ for copper(II) oxide in one sample. Nevertheless, only a leaching test can prove if the slag fulfills the requirements for a heavy-metal free slag, according to regulations.

\section{Conclusions}

This paper investigated the pyrometallurgical enrichment process of valuable metals from manganese nodules and explored the utilization of the manganese-bearing slag.

Pre-trials and further scale-up experiments highlighted the beneficial effects of fluxing by $\mathrm{SiO}_{2}$ in the smelting reduction process of manganese nodules. Optimal parameters were a smelting temperature of $1400{ }^{\circ} \mathrm{C}$ and the addition of $9.4 \mathrm{wt} \% \mathrm{SiO}_{2}$ to recover over $90 \%$ and up to $100 \%$ of cobalt, copper, molybdenum, nickel and manganese was successfully discarded into the slag to a significant extent $(>97 \%)$. The enrichment of valuable metals in an alloy while discarding gangue and manganese with the slag is an advantage of the process, since it significantly reduces the amount of material, which needs to be processed further by hydrometallurgical methods. 
The trials to produce ferromanganese showed that the manganese-bearing slag could be used as a resource to produce an alloy that conformed with the ASTM standard. Recovering manganese as a marketable alloy has two significant advantages, (i) the generation of revenue and (ii) by further reduction the total amount of slag is decreased and heavy-metals are reduced and collected in the metal, which is relevant for utilizing the slag as a mineral product, for example in the construction industry. Different fluxes and the amount of added fluxes were investigated. The results showed that the addition of $5-15 \mathrm{wt} \%$ of lime provided the best results. However, further studies and a scale-up are necessary especially for the second reduction step. Copper impurities are another problem in the alloy, which make further investigation of the copper behavior during the reduction and phase separation necessary. Furthermore, the utilization of the resulting slag as a mineral product has to be proven in supplementary studies, however, the chemical analysis does not show elevated contents for heavy-metals and is therefore promising.

Supplementary Materials: The following are available online at http:/ /www.mdpi.com/2075-163X/8/12/544/ s1, Table S1: Description of occurring phases from the phase diagram (Figure 5).

Author Contributions: M.S. designed, carried out and analyzed the ferromanganese experiments. D.F. designed, carried out and analyzed the manganese nodules smelting experiments. M.S. wrote the paper with significant contributions from T.K. and B.F. All authors read and approved the final manuscript.

Funding: This research was funded by internal BGR funding under the grant number A-0203002.A.

Acknowledgments: The German Federal Institute for Geosciences and Natural Resources (BGR) is acknowledged for the supply of raw nodules, financial and additional support.

Conflicts of Interest: The funding sponsors had no role in the design of the study; in the collection, analyses, or interpretation of data; and in the decision to publish the results. As part of the funding sponsor, T.K. contributed to writing the manuscript.

\section{References}

1. Rühlemann, C.; Knodt, S. Manganese nodule exploration \& exploitation from the deep ocean. J. Ocean Technol. 2015, 10, 13-21.

2. Hein, J.R.; Petersen, S. The geology of manganese nodules. In Deep Sea Minerals: Manganese Nodules, a Physical, Biological, Environmental and Technical Review; Beaudoin, Y.C., Baker, E., Eds.; Secretariat of the Pacific Community: Nouméa, New Caledonia, 2013; pp. 7-18. ISBN 978-82-7701-120-2.

3. Friedmann, D.; Pophanken, A.K.; Friedrich, B. Pyrometallurgical treatment of high manganese containing deep sea nodules. J. Sustain. Metal. 2017, 3, 219-229. [CrossRef]

4. Hein, J.R.; Koschinsky, A. Deep-ocean ferromanganese crusts and nodules. In Treatise on Geochemistry, 2nd ed.; Holland, H.D., Turekian, K., Eds.; Elsevier: Amsterdam, The Netherlands, 2014; pp. 273-291, ISBN 978-0-08-098300-4.

5. Sridhar, R.; Jones, W.E.; Warner, J.S. Extraction of copper, nickel and cobalt from sea nodules. J. Miner. Met. Mater. Soc. 1976, 28, 32-37. [CrossRef]

6. Grandell, L.; Lehtilä, A.; Kivinen, M.; Koljonen, T.; Kihlman, S.; Lauri, L.S. Role of critical metals in the future markets of clean energy technologies. Renew. Energy 2016, 95, 53-62. [CrossRef]

7. United States Geological Survey. Mineral Commodity Summaries-Cobalt 2018. Available online: https: // minerals.usgs.gov/minerals/pubs / commodity / cobalt/mcs-2018-cobal.pdf (accessed on 24 May 2018).

8. United States Geological Survey. Minerals Yearbook-Manganese 2014. Available online: https://minerals. usgs.gov/minerals/pubs/commodity/manganese/myb1-2014-manga.pdf (accessed on 14 September 2017).

9. Premchand, P.; Jana, R.K. Processing of polymetallic sea nodules: An overview. In Proceedings of the Third ISOPE Ocean Mining Symposium, Goa, India, 8-10 November 1999; International Society of Offshore and Polar Engineers: Cupertino, CA, USA, 1999; pp. 237-245.

10. Agarwal, J.C.; Beecher, N.; Davies, D.S.; Hubred, G.L.; Kakaria, V.K.; Kust, R.N. Processing of ocean nodules: A technical and economic review. J. Miner. Met. Mater. Soc. 1976, 28, 24-31. [CrossRef]

11. Sen, P.K. Metals and materials from deep sea nodules: An outlook for the future. Int. Mater. Rev. 2013, 55, 364-391. [CrossRef] 
12. Sahu, K.K.; Agarwal, S.; Mishra, D.; Agrawal, A.; Randhawa, N.S.; Godiwalla, K.M.; Jana, R.K. Nickel, cobalt and copper recovery from sea nodules by direct smelting process. In Proceedings of the Ni-Co 2013, San Antonio, TX, USA, 3-7 March 2013; Battle, T., Moats, M., Cocalia, V., Oosterhof, H., Alam, S., Eds.; Springer: Cham, Switzerland, 2013; pp. 291-298.

13. Kohga, T.; Imamura, M.; Takahashi, J.; Tanaka, N.; Nishizawa, T. Recovering iron, manganese, copper, cobalt, and high-purity nickel from sea nodules. J. Miner. Met. Mater. Soc. 1995, 47, 40-43. [CrossRef]

14. Bale, C.C.; Bélisle, E.; Chartrand, P.; Decterov, S.A.; Eriksson, G.; Gheribi, A.; Hack, K.; Jung, I.-H.; Melançon, J.; Pelton, A.D.; et al. Recent developments in Factsage thermochemical software and databases. In Celebrating the Megascale, Proceedings of the Extraction and Processing Division Symposium on Pyrometallurgy in Honor of David G.C. Robertson, San Diego, CA, USA, 16-20 February 2014; Mackey, P.J., Grimsey, E.J., Jones, R.T., Brooks, G.A., Eds.; Springer: Cham, Switzerland, 2014; pp. 141-148.

15. Olsen, S.E.; Tangstad, M.; Lindstad, T. Production of Manganese Ferroalloys; Tapir Akademisk Forlag: Trondheim, Norway, 2007; ISBN 978-82-519-2191-6.

16. Coudurier, L.; Hopkins, D.W.; Wilkomirsky, I. Fundamentals of Metallurgical Processes, 2nd ed.; Pergamon Press: Oxford, UK, 1985; ISBN 978-0-08-032536-1.

(C) 2018 by the authors. Licensee MDPI, Basel, Switzerland. This article is an open access article distributed under the terms and conditions of the Creative Commons Attribution (CC BY) license (http:/ / creativecommons.org/licenses/by/4.0/). 